\title{
Akuntabilitas Layanan Surat Izin Mengemudi Keliling di Jawa Tengah
}

\section{Accountability of Mobile Driving License Service In Central Java}

\author{
Muji Ediyanto, Kismartini, Retno Sunu Astuti \& Teuku Afrizal* \\ Magister Administrasi Publik, Fakultas Ilmu Sosial dan Ilmu Politik \\ Universitas Diponegoro, Indonesia
}

Diterima: 05 Juni 2021; Direview: 05 Juni 2021; Disetujui: 29 November 2021

\begin{abstract}
Abstrak
Penelitian ini bertujuan menganalisis akuntabilitas layanan Surat Izin Mengemudi (SIM) kelilingAkuntabilitas pelayanan adalah pertanggungjawaban penyelenggara pelayanan publik kepada masyarakat terhadap setiap keputusan dan tindakan. Justru, akuntabilitas menjadi motivasi bagi semua pemngku kepentingan untuk bertanggung jawab pada pelayanan yang disediakan bagi mewujudkan tata pemerintahan yang baik. Penelitian ini berpendekatan kualitatif-deskriptif dengan lokasi penelitian di wilayah kerja Polda Jawa Tengah. Data diperoleh melalui wawancara mendalam, observasi di lapangan dan dokumentasi. Hasil penelitian menunjukkan bahwa kinerja Ditlantas Polda Jawa Tengah belum optimal. Ini ditandai dengan ketidaksesuaian antara produk layanan SIM keliling dengan jumlah pemilik mobil penumpang dan sepeda motor. Kondisi ini dipengaruhi kuantitas dan kualitas sumber daya manusia/pegawai, tidak adanya kolaborasi kepada pihak lain dan rendahnya sosialisasi kepada masyarakat. Fasilitas layanan SIM keliling juga menjadi penyebab rendahnya kinerja Ditlantas Polda Jawa Tengah. Mobil sebagai fasilitas kunci layanan tidak memadai. Di sisi lain, layanan SIM keliling secara offline masih ditemukan di wilayah Jawa Tengah. Layanan ini tidak terintegrasi, sehingga mengurangi kualitas layanan SIM keliling, khususnya bagi masyarakat pendatang yang bukan berasal dari daerah lain,. Kesimpulannya bahwa akuntabilitas Ditlantas Polda Jawa Tengah terkait layanan SIM keliling masih tergolong rendah. Sehingga untuk meningkatkan akuntabilitas Ditlantas Polda Jawa Tengah harus melakukan evaluasi untuk menyusun kembali rencana dan konsep, membangun kolaborasi dan meningkatkan sosialisasi terkait layanan SIM keliling. Kata Kunci: Akuntabilitas; Layanan Surat Ijin Mengemudi; Keliling; Evaluasi Program
\end{abstract}

\begin{abstract}
This study aims to analyze the accountability of mobile driving license (SIM) services. Service accountability is the accountability of public service providers to the community for every decision and action. Instead, accountability is a motivation for all stakeholders to be responsible for the services provided to realize good governance. This research has a qualitative-descriptive approach with the research location in the working area of the Central Java Regional Police. Data were obtained through in-depth interviews, field observations and documentation. The results showed that the performance of the Ditlantas Polda Central Java was not optimal. This is indicated by the discrepancy between the mobile SIM service product and the number of owners of passenger cars and motorcycles. This condition is influenced by the quantity and quality of human resources/employees, the lack of collaboration with other parties and the low level of socialization to the community. The mobile SIM service facility is also the cause of the low performance of the Central Java Police Ditlantas. The car as a service key facility is not adequate. On the other hand, offline mobile SIM services are still found in the Central Java region. This service is not integrated, thus reducing the quality of mobile SIM services, especially for immigrants who are not from other regions. The conclusion is that the accountability of the Central Java Police Ditlantas regarding mobile SIM services is still relatively low. So that to increase the accountability of the Central Java Police Ditlantas, they must carry out an evaluation to rearrange plans and concepts, build collaboration and increase socialization related to mobile SIM services.
\end{abstract}

Keywords: Accountability; Sim Service; Mobile; Program Evaluation

How to Cite: Ediyanto, M. Kismartini, Astuti, R.S. \& Afrizal, T. (2022) Akuntabilitas Layanan Surat Izin Mengemudi Keliling Di Jawa Tengah. PERSPEKTIF, 11 (1): 77-87

*Corresponding author:

E-mail: teukurian@lecturer.undip.ac.id 


\section{PENDAHULUAN}

Pelayanan publik sering menjadi bahan diskusi di masyarakat karna pentingnya dan pengaruhnya terhadap kehidupan sehari-hari masyarakat (Hodgkinson dkk, 2017). Prinsipnya penyelenggaraan layanan publik sangat berbeda dengan pengelolaan layanan di sektor swasta. Layanan publik mencakup lebih banyak penyedia layanan dan pemangku kepentingan, sehingga membutuhkan akuntabilitas yang tinggi (Osborne dkk, 2013). Hal ini membuat layanan publik lebih kompleks dari layanan sektor swasta. Telah diketahui bahwa organisasi sektor publik merupakan organisasi yang lebih tidak homogen dan sangat kompleks. Domain sektor publik yang juga wilayahnya lebih luas dibandingkan sektor swasta (Mardiasmo 2006, Halim dan Kusufi, 2013). Justru hal yang sedemikian, membuat sifat layanan publik sangat kompleks dan praktiknya kerap dikritik oleh pemangku kepentingan kususnya masyarakat. Banyak dari masyarakat berulang kali melaporkan kesulitan dalam mengakses layanan publik, seperti pendidikan, perawatan kesehatan atau kesejahteraan sosial. Menurut Moynihan dkk (2015), ada tiga kesulitan yang dihadapi masyarakat dalam mengakses layanan publik, yaitu (a) biaya tinggi. Setiap masyarakat harus belajar tentang layanan publik dan cara mengajukannya; (b) Biaya psikologis. Masyarakat sering dihadapkan pada stigma buruk tentang layanan publik dan birokrasi; dan (c) Biaya kepatuhan. Masyarakat dipaksa untuk mematuhi aturan dan persyaratan formal layanan.

Pelayanan Surat Izin Mengemudi (SIM) adalah salah satu layanan publik yang dinilai sulit dalam mengakesnya. Masalah antrian panjang, informasi pembuatan SIM yang tidak detail dan standard operasional prosedur layanan yang tidak konsisten menjadi keluhan umum bagi masyarakat (Sarmini, 2019; Fidianingsih \& Fanida, 2020; Handrian, 2019). Masalah ini juga ditemukan pada pelayanan SIM keliling, yang merupakan terobosan baru bagi kepolisian dalam memberikan layanan. Tapi upaya tersebut kadang-kadang tidak diimbangi dengan fasilitas yang memadai, sehingga terkesan tidak ada pembeda antara layanan SIM di kantor dengan layanan SIM keliling. Misalnya efisiensi waktu, masyarakat masih mengeluhkan waktu layanan yang tidak sesuai dengan standard operasional prosedur.
Waktu yang dibutuhkan untuk layanan SIM keliling adalah 25 menit. Dalam praktiknya, masyarakat harus menunggu dua sampai tiga jam pelayanan (Diansari, 2016; Efriani, 2020). Sarana layanan SIM keliling juga menjadi persoalan. Misalnya Kabupaten Semarang dengan luas wilayah 946,86 $\mathrm{km}^{2}$ hanya memiliki satu unit mobil layanan SIM keliling (Hadmiarso \& Kismartini, 2020). Sarana seperti ini sangat tidak memungkinkan wujudnya layanan publik dengan baik.

Beberapa fenomena di atas tersebut menggambarkan layanan SIM keliling belum wujud dengan optimal. Artikel ini ditulis atas pertimbnagan beberapa fenomena di atas. Pemerintah menginginkan masyarakat untuk tertib sebagai pengguna jalan. Pemerintah juga memberi ancaman kepada masyarakat yang tidak memiliki SIM, dengan pidana paling lama empat bulan kurungan atau denda paling banyak satu juta rupiah. Peraturan ini tertuang dalam Undang-Undang No. 22 Tahun 2009 tentang Lalu Lintas Dan Angkutan Jalan dalam Pasal 281. Hal ini tentunya kurang relevan dengan layanan SIM yang diberikan kepada masyarakat. Kualitas layanan SIM sangat mempengaruhi kesadaran masyarakat untuk mengajukan permohonan pembuatan SIM. Meskipun keengganan masyarakat mengajukan permohonan SIM berdampak negatif bagi mereka sendiri, tetapi poinnya adalah pemerintah dalam hal ini pihak Kepolisian gagal dalam menjalankan tugas sebagai pemberi layanan kepada masyarakat.

Beberapa kajian tentang layanan SIM keliling telah dipaparkan dalam berbagai penelitian terdahulu. Hadmiarso \& Kismartini (2020) meneliti tentang kualitas pelayanan surat izin mengemudi wisata di Kabupaten Semarang. Tujuan kajiannya menganalisis kualitas pelayanan SIM wisata di Kabupaten Semarang dan faktor-faktor yang mempengaruhinya. Pelayanan SIM di Kabupaten Semarang secara umum tergolong baik. Dalam penerapannya, ada ditemukan kendala terutama di aspek infrastruktur. Diantara kendala tersebut adalah mobil untuk layanan hanya tersedia satu unit, kursi tunggu dan tenda belum tersedia, serta masih terbatasnya petugas dalam memberikan layanan SIM. Rafidah (2019) pernah meneliti tentang masalah dan solusi dalam layanan publik bergerak berbantuan teknologi informasi: kasus pelayanan SIM keliling di 
Sleman. Penelitiannya menemukan ada tiga hambatan dalam penerapannya, yaitu (a) hambatan teknik, seperti ketidakintegrasian data; (b) hambatan organiasi, seperti kurangnya strategi perencanaan dan evaluasi; dan (c) hambatan infrastruktur, seperti terbatasnya jumlah komputer. Purnamasari dkk (2020) juga pernah meneliti tentang kualitas pelayanan publik dalam pembuatan surat izin mengemudi kendaraan motor di Polres Karawang. Mereka menemukan bahwa layanan belum berjalan efektif dan belum mampu meningkatkan kepuasan kepada pelanggan atau masyarakat. Faktor infrastruktur juga menjada kendala utama dalam penerapannya. Keterbatasaan infrastruktur telah menjadi keluhan masyarakat dalam layanan pembuatan SIM di Karawang.

Kajian-kajian di atas menginformasikan bahwa layanan SIM keliling di beberapa daerah belum berjalan efektif. Faktor yang paling mempengaruhi ketidakefektifan layanan SIM keliling berada di pihak pemberi layanan. Pemberi layanan di sini adalah institusi kepolisian Daerah (Polda). Beberapa kajian terdahulu umumnya meneliti layanan SIM di kabupaten/kota dan menilai kualitas layanan yang diberikan. Penelitian ini mengambil lokus pada level provinsi untuk memperkaya dan memperdalam analisis layanan SIM keliling. Fokus penelitian ini pada aspek akuntabilitas, yang mengarah pada kinerja organisasi.

Akuntabilitas pelayanan publik adalah kewajiban yang harus dilaksanakan secara utuh oleh setiap instansi dan unit pelayanan instansi pemerintah sesuai dengan tugas dan fungsinya. Diantara indikatornya adalah kinerja instansi dan fasilitas layanan publik (Keputusan Menteri Pendayagunaan Negara No. 63 Tahun 2003). Menurut Sahid \& Kesuma (2016), akuntabilitas adalah ukuran untuk menilai kesesuaian layanan publik dengan kebutuhan masyarakat. Akuntabilitas dalam dekade terakhir ini dipercaya sebagai alat untuk mendorong wujdunya good governanc, karena berhubungan dengan kinerja organisasi, sumber daya manusia dan kepuasan masyarakat (Matsiliza \& Zonke, 2017). Dalam konteks ini, akuntabilitas layanan SIM keliling menjadi tantangan tersendiri termasuk kepatuhan dan konsistensi implementasi kebijakan. Oleh sebab itu, penelitian ini bertujuan menganalisis akuntabilitas layanan SIM keliling di Jawa Tengah.

\section{Bagan 1. Kerangka Teori}

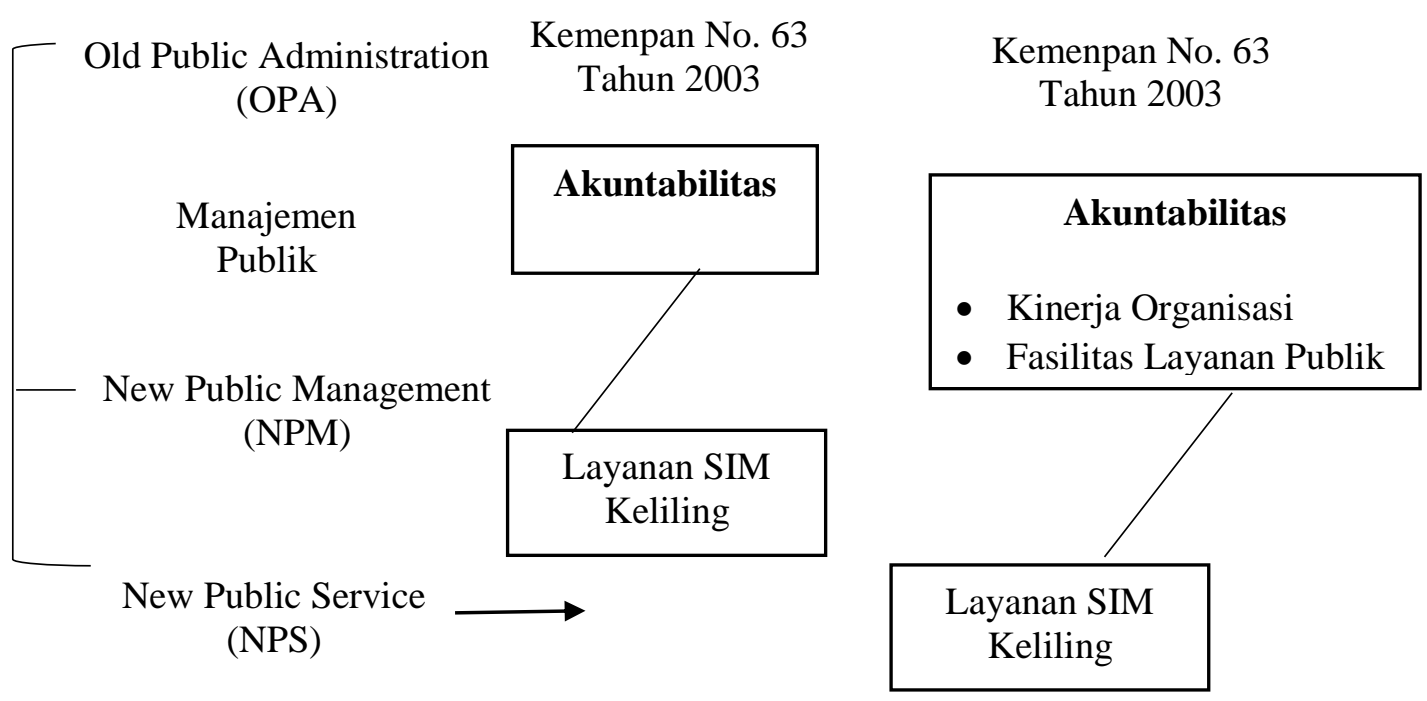

Sumber: Diolah dari Beberapa Literatur, 2021.

\section{METODE PENELITIAN}

Penelitian ini bersifat field research, dengan pendekatan kualitatif-deskriptif. Lokasi penelitian ini adalah Direktorat Lalu Lintas Kepolisian Daerah (Ditlantas Polda) Jawa Tengah. Ketertarikan peneliti melakukan penelitian ini adalah masih sedikit kajian yang mengambil lokus pada level provinsi. Di sisi lain, pengambilan wilayah secara luas dapat menemukan informasi lebih kaya, sehingga rekomendasi dapat dibentuk dengan mudah dan mendalam. Data primer dikumpulkan 
melalui observasi dan wawancara mendalam. Dalam pengumpulan data primer, peneliti menggunakan pedoman wawancara sebagai instrumen penelitian yang bersifat open ended question. Pemilihan informan dilakukan dengan purposive sampling. Informan dalam penelitian ini adalah Kepala seksi SIM Sub direktorat registrasi dan identifikasi (subdit regident) Ditlantas Polda Jawa Tengah, petugas yang menjadi pelaksana layanan SIM keliling dan beberapa masyarakat sebagai penerima layanan SIM keliling. Data sekunder dihimpun melalui laporan-laporan pemerintah, website Kepolisian Daerah Jawa Tengah, literatur dan penelitian terdahulu yang relevan serta berbagai informasi tambahan lainnya. Semua data akan diintegrasikan untuk menemukan informasi dalam menjawab tujuan penelitian.

Teknik analisis data dilakukan dengan tiga tahapan. Pertama adalah kondensasi data. Data yang dikumpulkan dipilih dan dimodifikasi secara sistematis berdasarkan tujuan penelitian. Kedua adalah penyajian data. Peneliti menghubungkan semua data ke teori yang digunakan, literatur dan hasil penelitian terdahulu yang relevan. Ketiga adalah penarikan kesimpulan. Semua hasil penelitian dan pembahasan dikombinasikan untuk membentuk sebuah informasi yang akurat, agar dapat memberikan rekomendasi yang tepat pada akhir penelitian (Miles dkk, 2014).

Bagan 2. Teknik Analisis Data.

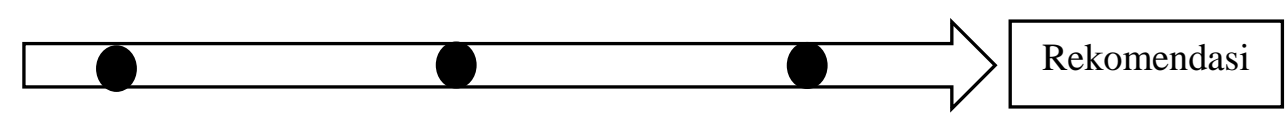

Kondensasi Data Penyajian Data Penarikan Kesimpulan

Sumber: Miles dkk, 2014.

\section{HASIL DAN PEMBAHASAN}

Pelayanan SIM keliling di Jawa Tengah berpedoman pada telegram Ditlantas Polda Jawa Tengah tanggal 7 Juni 2007 kepada Kepala Kepolisian Wilayah (Kapolwil) jajaran, Kepala Kepolisian Wilayah Kota Besar (Kapolwiltabes) Semarang, Kepala Kepolisian Kota Besar (Kapoltabes) Surakarta dan Kepala Kepolisian Resort (Kapolrest) jajaran tentang rencana pemberlakuan SIM keliling di Jawa Tengah. Pelayanan SIM keliling hanya melayani perpanjangan SIM A (mobil penumpang dan barang perseorangan) dan SIM C (sepeda motor). Tujuan layanan SIM keliling adalah memberi kemudahan bagi masyarakat dan mendekatkan institusi kepolisian kepada masyarakat.

Mekanisme layanan SIM keliling di Jawa Tengah diawali secara offline. Mekanisme ini hanya melayani masyarakat yang sesuai dengan alamat di Kartu Tanda Penduduk (KTP). Misalnya layanan SIM keliling Kabupaten Kendal, layanannya hanya bisa diberikan kepada masyarakat Kendal. Penerapan secara offline kemudian mendapat kritikan dari berbagai pemangku kepentingan, khususnya masyarakat. Alasan utama adalah KTP yang dimiliki masyarakat sudah berifat elektronik (e-KTP) dan terintegrasi. Ini artinya layanan
SIM keliling dapat dilaksanakan secara online dan masyarakat di luar daerah dapat dilayani untuk perpanjangan SIM A dan C.

Layanan SIM keliling secara online akhirnya diterapkan oleh Ditlantas Polda Jawa Tengah. Layanan tersebut sudah dilakukan selama tiga tahun. sebagian wilayah di Jawa Tengah belum menggunakan layanan SIM keliling secara online, seperti wilayah Banyumas, Cilacap, Pati dan beberapa daerah lainnya.

Penerapan layanan SIM keliling secara offline dan online perlu ditinjau lagi, terutama dalam aspek akuntabilitas. Akuntabilitas di sini mengarah pada kinerja organisasi dan fasilitas layanan SIM keliling yang diberikan oleh Ditlantas Polda Jawa Tengah. Dua indikator ini dapat menunjukkan tinggi atau rendahnya akuntabilitas Ditlantas Polda Jawa Tengah terhadap program yang telah ditetapkan secara bersama. Program yang telah diputuskan secara bersama harus dilaksanakan secara konsisten dan berkesinambungan. Selain sebagai pemeberi layanan, Ditlantas Polda Jawa Tengah juga berfungsi meningkatkan interaksi kepada masyarakat agar wujudnya good governance yang baik. 
Akuntabilitas Kinerja Layanan SIM Keliling

Akuntabilitas kinerja dalam dekade terakhir ini dipercaya sebaga alat untuk mendorong wujdunya good governance (Matsiliza \& Zonke, 2017). Dalam konteks ini, akuntabilitas hadir untuk memastikan kinerja Ditlantas Polda Jawa Tengah dalam memberikan layanan SIM keliling, karena berkaitan dengan semua akses layanan yang efektif dan efisien.

Layanan SIM keliling di Jawa Tengah hanya beroperasi untuk perpanjangan SIM A dan C. Syarat utama untuk mendapatkan layanan SIM adalah berumur $>17$ tahun. Badan Pusat Statistik (BPS) Jawa Tengah (2020) melaporkan bahwa penduduk Provinsi Jawa Tengah adalah 34.718.204 jiwa Jumlah kelompok usia $>17$ tahun adalah 21.900.145 jiwa. Masyarakat di Jawa Tengah yang memiliki mobil penumpang dan sepeda motor mengalami peningkatan dalam tiga tahun terakhir (lihat gambar 1). Berikut adalah pertumbuhan jumlah pemilik mobil penumpang dan sepeda motor di Jawa Tengah.

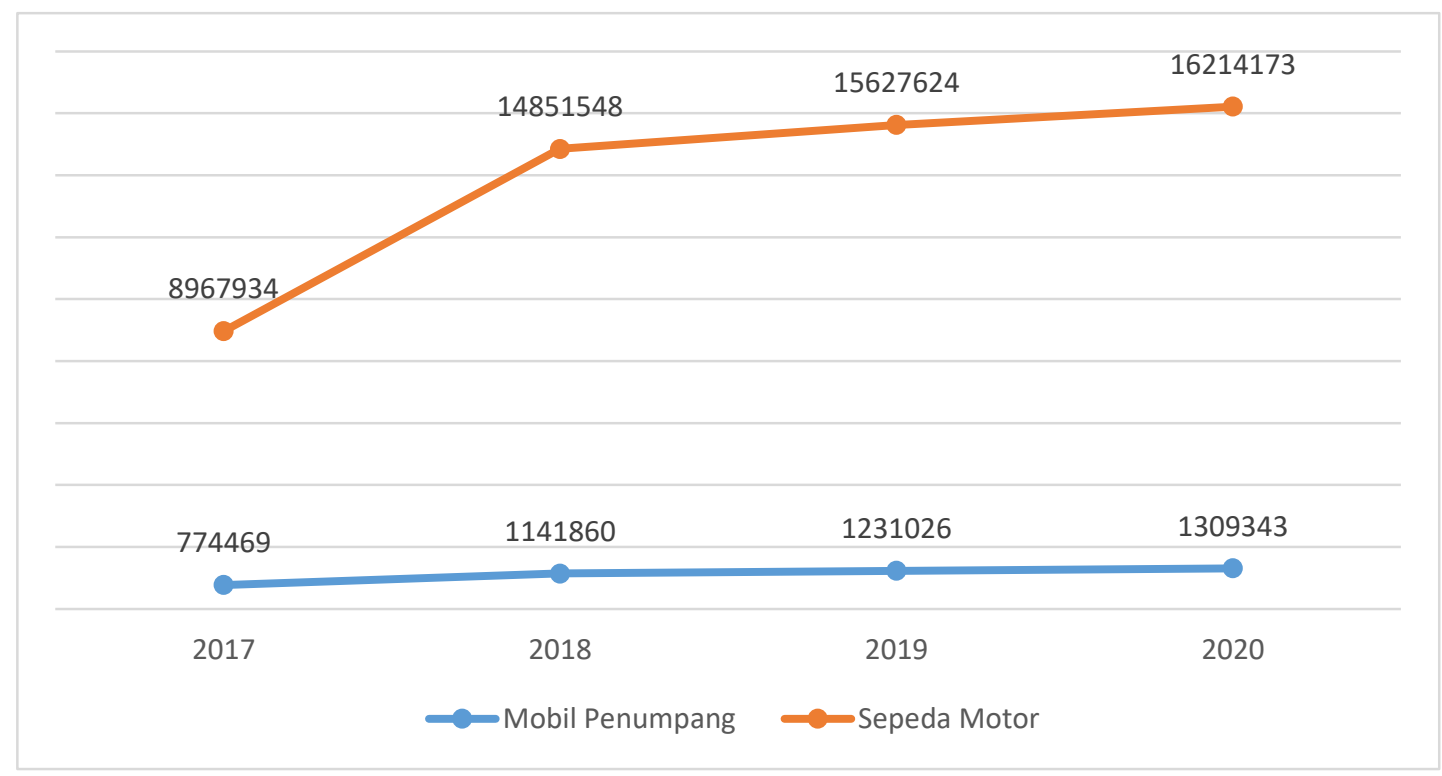

Gambar. 1 Pertumbuhan Pemilik Mobil Penumpang dan Sepeda Motor Di Jawa Tengah. Sumber: BPS Jawa Tengah, 2020 .

Peningkatan pemilik mobil penumpang dan sepeda motor sejalan dengan meningkatnya layanan SIM di Jawa Tengah. Terkait perpanjangan SIM A dan C, jumlah pengajuan atau pelayanan yang diberikan masih sangat sedikit dibanding jumlah pemilik mobil penumpang dan sepeda motor di Jawa Tengah. Setengah dari wiliyah Jawa Tengah bahkan tidak mendapat satu pelanggan untuk diberikan layanan SIM keliling di tahun 2019 (lihat tabel 1). Fenomena ini tentunya menggambarkan masih banyak masyarakat di wilayah Jawa Tengah yang masa aktif SIM sudah habis. Ini merupakan sebuah pelanggaraan lalu lintas sebagai pengguna jalan. Berikut adalah data layanan SIM keliling di Jawa Tengah.

Total pemilik mobil penumpang dan sepeda motor tahun 2019 adalah 16.858 .650 unit. Produk layanan SIM keliling (A \& C) di Jawa Tengah tahun 2019 adalah 204.165. Angka ini masih sangat rendah bila dibanding dengan jumlah pemilik mobil penumpang dan sepeda motor. Produk layanan SIM keliling tahun 2020 mengalami penurunan (lihat tabel 2). Penurunannya tergolong drastis, sehingga tidak relevan dengan total pemilik mobil penumpang dan sepeda motor di jawa tengah tahun 2020. Berikut adalah data produk layanan SIM keliling di Jawa Tengah tahun 2020. 
Muji Ediyanto, Kismartini, Retno Sunu Astuti, \& Teuku Afrizal, Akuntabilitas Layanan Surat Izin

Tabel 1. Jumlah Layanan SIM Keliling di Jawa Tengah.

\begin{tabular}{|c|c|c|c|c|c|c|}
\hline No & Wilayah & SIM A & SIM C & Wilayah & SIM A & SIM C \\
\hline 1 & Banyumas & 1919 & 6342 & Purbalingga & $\mathrm{O}$ & $\mathrm{O}$ \\
\hline 2 & Cilacap & 3529 & 14192 & Banjarnegara & $\mathrm{O}$ & o \\
\hline 3 & Pemalang & 2041 & 9893 & Kota Pekalongan & o & o \\
\hline 4 & Kab.Tegal & 225 & 1264 & Batang & o & o \\
\hline 5 & Brebes & 7 & 255 & Kota Tegal & $\mathrm{O}$ & $\mathrm{O}$ \\
\hline 6 & Pati & 426 & 2327 & Jepara & $\mathrm{O}$ & o \\
\hline 7 & Kudus & 22 & 51 & Rembang & o & o \\
\hline 8 & Blora & 26 & 120 & Sukoharjo & o & o \\
\hline 9 & Grobogan & 11 & 82 & Boyolali & o & 1 \\
\hline 10 & Klaten & 121 & 457 & Sragen & $\mathrm{O}$ & o \\
\hline 11 & Surakarta & 939 & 2985 & Karanganyar & o & o \\
\hline 12 & Kab.Magelang & 55 & 264 & Wonogiri & $\mathrm{O}$ & $\mathrm{O}$ \\
\hline 13 & Purwerejo & 237 & 1444 & Kota Magelang & $\mathrm{o}$ & $\mathrm{O}$ \\
\hline 14 & Kebumen & 1078 & 5153 & Wonosobo & $\mathrm{O}$ & o \\
\hline 15 & Temanggung & 568 & 3146 & Salatiga & o & o \\
\hline 16 & Kota Semarang & 34242 & 105614 & Kendal & $\mathrm{o}$ & $\mathrm{O}$ \\
\hline 17 & Kab.Semarang & 785 & 4345 & Demak & $\mathrm{o}$ & $\mathrm{O}$ \\
\hline \multirow{2}{*}{\multicolumn{2}{|c|}{ Jumlah }} & \multirow{2}{*}{46231} & \multirow{2}{*}{157934} & Kab. Pekalongan & o & $\mathrm{O}$ \\
\hline & & & & Jumlah & o & 1 \\
\hline
\end{tabular}

Sumber: Subditregident Ditlantas Polda Jawa Tengah, 2019.

Tabel 2. Jumlah Layanan SIM Keliling di Jawa Tengah.

\begin{tabular}{|c|c|c|c|c|c|c|}
\hline No & Wilayah & SIM A & SIM C & Wilayah & SIM A & SIM C \\
\hline 1 & Pemalang & 1498 & 6154 & Banyumas & $\mathrm{O}$ & $\mathrm{O}$ \\
\hline 2 & Kudus & 704 & 2789 & Cilacap & o & o \\
\hline 3 & Klaten & 176 & 682 & Purbalingga & o & o \\
\hline 4 & Magelang & 12 & 53 & Banjarnegara & $\mathrm{O}$ & $\mathrm{O}$ \\
\hline 5 & Purworejo & 239 & 1321 & Kota Pekalongan & $\mathrm{O}$ & 0 \\
\hline 6 & Kebumen & 856 & 4332 & Kab.Pekalongan & $\mathrm{O}$ & o \\
\hline 7 & Kota Semarang & 11246 & 31270 & Batang & o & 0 \\
\hline 8 & Kab.Semarang & 598 & 2860 & Kota Tegal & $\mathrm{O}$ & $\mathrm{O}$ \\
\hline 9 & Kendal & 582 & 2507 & Brebes & $\mathrm{O}$ & o \\
\hline 10 & & & & Pati & o & o \\
\hline 11 & & & & Jepara & $\mathrm{O}$ & $\mathrm{O}$ \\
\hline 12 & & & & Rembang & $\mathrm{O}$ & o \\
\hline 13 & & & & Grobogan & o & $\mathrm{O}$ \\
\hline 14 & & & & Sukoharjo & o & $\mathrm{O}$ \\
\hline 15 & & & & Boyolali & o & o \\
\hline 16 & & & & Sragen & o & o \\
\hline 17 & & & & Karanganyar & o & o \\
\hline 18 & & & & Wonogiri & o & o \\
\hline 19 & & & & Surakarta & $\mathrm{O}$ & $\mathrm{O}$ \\
\hline 20 & & & & Kota Magelang & $\mathrm{O}$ & $\mathrm{O}$ \\
\hline 21 & & & & Temanggung & o & $\mathrm{O}$ \\
\hline 22 & & & & Wonosobo & $\mathrm{O}$ & $\mathrm{o}$ \\
\hline 23 & & & & Salatiga & o & $\mathrm{o}$ \\
\hline 24 & & & & Demak & $\mathrm{O}$ & $\mathrm{O}$ \\
\hline \multicolumn{2}{|c|}{ Jumlah } & 15944 & 52113 & Jumlah & $\mathrm{O}$ & $\mathrm{O}$ \\
\hline
\end{tabular}

Sumber: Subditregident Ditlantas Polda Jawa Tengah, 2020.

Produksi layanan SIM keliling (A \& C) tahun 2020 adalah 68.057. Jumlah ini menurun dari tahun 2019 dan masih tergolong sangat rendah bila dibanding dengan total pemilik mobil penumpang dan sepeda motor tahun 2020, yaitu 17.523.516 unit. Masalah krusial 
yang muncul dari kedua data di atas adalah sebagian besar wilayah di Jawa tengah tidak mendapatkan pelanggan yang mengajukan perpanjangan SIM A \& C, baik tahun 2019 maupun 2020. Ini menunjukkan bahwa tingkat akuntabilitas terhadap program SIM keliling di Jawa Tengah tergolong rendah. Peneliti menilai rendahnya tingkat akutabilitas disebabkan rendahnya kinerja institusi kepolisian di tingkat provinsi dan kabupaten/kota terkait layanan SIM keliling.

Ada beberapa unsur yang mempengaruhi kinerja layanan SIM keliling di Jawa Tengah. Pertama adalah Sumber Daya Manusia (SDM). Menurut Guest (2011) dan Chao \& Shih (2018), SDM dan kinerja layanan merupakan unsur yang tidak bisa pisahkan. Ini karena kualitas SDM akan mempengaruhi kualitas layanan dan kinerja organisasi. Dalam konteks ini, SDM yang melayani masyarakat terkait perpanjangan SIM kurang memadai, baik secara kuantitas maupun kualitas. Belum ada penunjukan pegawai secara konsisten dalam melayani SIM keliling, sehingga kerap terjadi pergantian pegawai. Pergantian tersebut cenderung kurang memahami kondisi lapangan secara utuh, yang mengakibatkan layanan SIM keliling kurang optimal.

Pegawai yang beroperasi di lapangan juga dipengaruhi oleh model implementasi yang diberikan oleh institusi kepolisian. Dalam perspektif manajemen publik, kualitas layanan publik bergantung bagaimana gaya implementasi yang diputuskan oleh organisasi (Andrews dkk, 2017). Dalam konteks ini, gaya implementasi layanan SIM keliling dipengaruhi oleh tingkat analisis dan evaluasi kinerja pegawai. Analisis dan evaluasi setiap kebijakan atau program seharusnya dilakukan setiap bulan atau setiap semester, namun hal itu jarang dilaksanakan. Misalnya evaluasi program, yang memiliki peran strategis dalam memberikan informasi yang dibutuhkan. Informasi dari hasil evaluasi dapat mendorong munculnya argumentasi publik, sehingga membantu memilih alternatif dalam penyelesaian masalah. Menurut McLaughlin dkk (2009), evaluasi layanan publik merupakan sarana untuk meningkatkan produk layanan publik lebih baik di masa depan (Hodgkinson dkk, 2017). Ditlantas Polda Jawa Tengah dalam praktiknya jarang menganalisis dan mengevaluasi kinerja pegawai terkait layanan SIM keliling. Kondisi ini menggambarkan bahwa institusi kepolisian di Jawa Tengah belum maksimal menyusun rencana terhadap model implementasi SIM keliling,

Kedua adalah kolaborasi. Menurunya produksi layanan SIM keliling di Jawa Tengah dipengaruhi oleh kolaborasi yang dibangun oleh institusi kepolisian. Belum ada kolaborasi selama ini yang dibangun oleh institusi kepolisian sejak diterapkannya SIM keliling. Dampaknya adalah layanan SIM keliling tidak terencana dan tidak terjadwal dalam implementasinya. Masyarakat pada akhirnya tidak siap untuk mengurus perpanjangan SIM, karena jadwal layanan belum diinformasikan dengan jelas.

Kolaborasi kepada pemangku kepentingan lainnya merupakan perkara penting untuk mewujudkan implementasi kebijakan atau program dengan efektif. Kolaborasi ini tidak terbatas antara pemerintah dengan pemerintah, tetapi juga antara pemerintah dengan swasta (Sun, 2017). Kolaborasi dalam layanan publik dianggap dapat mendorong tata kelola, membentuk jaringan dengan cara yang konstruktif dan efisien (Kekez et al., 2018). Kolaborasi dalam konteks ini ditujukan untuk membangun kerjasama antara institusi kepolisian tingkat provinsi atau kabupaten/kota di Jawa Tengah dengan pemangku kepentingan lainnya. Misalnya, institusi kepolisian berkolaborasi dengan perusahaan A. Perusahaan tersebut akan menyiapkan karyawan-karyawan pada waktu tertentu untuk mendapatkan pelayanan SIM keliling. Jadwal yang telah ditetapkan akan dilaporkan kepada institusi kepolisian, sehingga pada jadwal tersebut diadakan pelayanan perpanjangan SIM dengan baik.

Ketiga adalah sosialisasi. Salah satu penyebab produk layanan SIM keliling di Jawa Tengah belum optimal adalah rendahnya sosialisasi kepada masyarakat atau pihak lainnya. Sosialisasi atau komunikasi antara pemerintah dengan masyarakat dibutuhkan untuk meningkatkan pengetahuan dan kesadaran masyarakat dalam suatu kegiatan (Baú, 2018). Dalam konteks ini, pengetahuan dan kesadaran masyarakat untuk mengajukan perpanjangan SIM melalui layanan SIM keliling tergolong rendah. Ini terlihat dari data produksi layanan SIM tahun 2019 dan tahun 2020. Tingkat pengetahuan dan kesadaran yang rendah juga tidak terlepas dari layanan 
SIM keliling yang tidak terencana dan tidak terjadwal.

Berdasarkan analisis di atas, dapat dipahami bahwa layanan SIM keliling di Jawa Tengah belum memberikan manfaat secara menyeluruh. Realita ini bertolak belakang dengan harapan dibentuknya program layanan SIM keliling. Beberapa faktor penghambat yang ditemukan dalam implementasi layanan SIM keliling di Jawa Tengah telah mengurangi tujuan program terebut.

\section{Akuntabilitas Fasilitas Layanan SIM Keliling}

Fasilitas layanan publik merupakan unsur penting yang harus direncanakan dan dikelola untuk memastikan kualitas layanan (Lee \& Kim, 2014). Fasilitas layanan harus menjadi fokus dalam memberikan layanan publik. Dalam konteks ini, fasilitas utama layanan SIM keliling di Jawa Tengah adalah mobil. Ketersediaan mobil SIM keliling yang memadai merupakan bentuk akuntabilitas institusi kepolisian Jawa Tengah terhadap program layanan SIM keliling. Ketersediaan mobil tersebut harus memadai secara kuantitas dan kualitas.

Ada dua layanan SIM keliling di Jawa Tengah, yaitu secara offline dan online. Kedua mekanisme ini harus dipastikan kondisi mobil dan tahun distribusi. Kedua aspek tersebut sangat mempengaruhi kinerja dan kualitas layanan SIM keliling. Selain untuk memberi kenyamanan dan kepuasan kepada masyarakat, kelengkapan fasilitas juga mendorong motivasi pegawai untuk memberikan layanan yang lebih baik. Di sisi lain, ketersediaan mobil juga menjadi perkara penting. Hal ini karena masing-masing kabupaten/kota di Jawa Tengah memiliki wilayah yang tergolong luas. Keterbatasan jumlah mobil akan menghambat implementasi layanan SIM keliling dengan baik. Dalam konteks ini, Satuan Penyelenggara Administrasi SIM (Satpas) di setiap wilayah Jawa tengah tidak memiliki ketersediaan mobil layanan SIM yang cukup (lihat tabel 3). Berikut adalah jumlah dan kondisi mobil SIM keliling secara online di Jawa Tengah.

Tabel 3. Jumlah dan Kondisi Mobil SIM Keliling Online di Wilayah Jawa Tengah.

\begin{tabular}{|c|c|c|c|c|c|c|c|}
\hline \multirow{2}{*}{ No } & \multirow{2}{*}{ Wilayah } & \multirow{2}{*}{ Jml } & \multirow{2}{*}{$\begin{array}{l}\text { Tahun } \\
\text { Distribusi }\end{array}$} & \multicolumn{2}{|c|}{ Kondisi } & \multirow{2}{*}{ Online } & \multirow{2}{*}{ Ket } \\
\hline & & & & $\bar{B}$ & $\mathrm{R}$ & & \\
\hline 1. & Satpas Magelang & 1 & 2015 & 1 & & Korlantas Polri & OPS \\
\hline 2. & Satpas Pemalang & 1 & 2015 & 1 & & Korlantas Polri & OPS \\
\hline 3. & Satpas Klaten & 1 & 2015 & 1 & & Korlantas Polri & OPS \\
\hline 4. & Satpas Kudus & 1 & 2016 & 1 & & Korlantas Polri & OPS \\
\hline 5. & Satpas Kebumen & 1 & 2016 & 1 & & Korlantas Polri & OPS \\
\hline 6. & Satpas Semarang & 1 & 2016 & 1 & & Korlantas Polri & OPS \\
\hline 7. & Satpas Blora & 1 & 2018 & 1 & & Korlantas Polri & OPS \\
\hline 8. & Satpas Purworejo & 1 & 2018 & 1 & & Korlantas Polri & OPS \\
\hline 9. & Satpas Kendal & 1 & 2019 & 1 & & Korlantas Polri & OPS \\
\hline \multirow{2}{*}{10.} & \multirow{2}{*}{ Satpas Polrestabes Semarang } & 1 & 2015 & 1 & & Korlantas Polri & OPS \\
\hline & & & 2016 & 1 & & Korlantas Polri & OPS \\
\hline \multirow[t]{2}{*}{11.} & Polda Backup & & 2017 & 1 & & Korlantas Polri & OPS \\
\hline & Semarang & 2 & 2016 & 2 & & Korlantas Polri & OPS \\
\hline 12. & Satpas Polresta Surakarta & 1 & 2007 & 1 & & Korlantas Polri & Tidak OPS \\
\hline \multicolumn{2}{|c|}{ JUMLAH } & 15 & & 15 & & & \\
\hline
\end{tabular}

Sumber: Subditregident Ditlantas Polda Jawa Tengah, 2020.

Keterangan

B : Baik

R : Rusak

OPS : Operasional

Jumlah wilayah di Jawa Tengah yang menyediakan layanan SIM keliling secara online adalah 12 wilayah. Wilayah yang menggunakan mobil layanan SIM keliling lebih dari satu hanya Polrestabes Semarang. Masing-masing wilayah yang menyediakan satu mobil untuk layanan
SIM keliling tergolong belum cukup. Satu wilayah bahkan menggunakan mobil layanan SIM keliling secara online tidak bersifat operasional, yaitu Satpas Polresta Surakarta. Sifat tidak operasional tersebut disebabkan kendala dengan modemnya. Kondisi ini 
menunjukkan bahwa fasilitas layanan SIM keliling secara online belum memadai. Fenomena ini berbanding lurus dengan rendahnya kinerja dan kualitas layanan SIM keliling di Jawa Tengah. Fenomena ini juga ditemukan pada fasilitas layanan SIM keliling secara offline (lihat tabel 4). Selain kuantitas mobil, kondisi dan tahun distribusi mobil layanan SIM keliling secara offline menjadi persoalan dalam implementasinya. Ada lima mobil layanan SIM keliling secara offline berstatus rusak. Kondisi mobil ini dipengaruhi oleh tahun distribusi mobil yang tergolong lama. Permasalahan ini telah mengurangi tingkat akuntabilitas fasilitas layanan SIM keliling secara offline di Jawa Tengah. Berikut adalah jumlah mobil layanan SIM keliling secara offline di Jawa Tengah.

Tabel 4. Jumlah Mobil Layanan SIM Keliling Secara Offline di Jawa Tengah.

\begin{tabular}{|c|c|c|c|c|c|c|}
\hline \multirow[b]{2}{*}{ No } & \multirow{2}{*}{ Lokasi } & \multirow[b]{2}{*}{ Jml } & \multirow{2}{*}{$\begin{array}{l}\text { Tahun } \\
\text { Distribusi }\end{array}$} & \multicolumn{2}{|c|}{ Kondisi } & \multirow[b]{2}{*}{ Ket } \\
\hline & & & & $\overline{\mathbf{B}}$ & $\mathbf{R}$ & \\
\hline 1 & Satpas Polres Tegal & 1 & 2013 & 1 & & Perangkat Lama \\
\hline 2 & Satpas Polres Banyumas & 1 & 2007 & 1 & & Perangkat Lama \\
\hline 3 & Satpas Polres Cilacap & 1 & 2007 & 1 & & Perangkat Lama \\
\hline 4 & Satpas Polres Pati & 1 & 2007 & 1 & & Perangkat Lama \\
\hline 5 & Satpas Polres Brebes & 1 & 2007 & 1 & & Perangkat Lama \\
\hline 6 & Satpas Polres Batang & 1 & 2007 & & 1 & Perangkat Lama \\
\hline 7 & Satpas Polres Jepara & 1 & 2007 & & 1 & Perangkat Lama \\
\hline 8 & Satpas Polres Rembang & 1 & 2007 & & 1 & Perangkat Lama \\
\hline 9 & Satpas Polres Sukoharjo & 1 & 2007 & & 1 & Perangkat Lama \\
\hline \multirow{2}{*}{10} & Polda Backup Po & & 2013 & 1 & & \multirow{2}{*}{-Perangkat Lama } \\
\hline & Semarang & 3 & 2007 & 2 & 1 & \\
\hline \multicolumn{2}{|c|}{ Jumlah } & 13 & & 8 & 5 & \\
\hline
\end{tabular}

Sumber: Subditregident Ditlantas Polda Jawa Tengah, 2020.

Isu yang muncul dalam kasus layanan SIM keliling secara offline di Jawa Tengah adalah isu pengadopsian teknologi dalam tata kelola pemerintahan atau layanan publik $(e-$ government). E-government merupakan instrumen yang membawa manfaat bagi pemerintah, swasta dan masyarakat, seperti efisiensi, terbangunnya komunikasi dan koordinasi antar pemangku kepentingan serta peningkatan akuntabilitas pemerintah (Ashaye \& Irani, 2019).

Pertumbuhan dan perkembangan wilayah di Jawa Tengah yang tergolong cepat, disebabkan pengadopsian teknologi dalam tata kelola pemerintahan. Pengadopsian ini juga seharusnya diterapkan pada semua layanan publik, termasuk layanan SIM keliling. Dalam konteks ini, ada 10 wilayah yang masih menggunakan layanan publik tradisional (offline). Layanan seperti ini tidak relevan dengan identitas warga negara yang sudah bersifat online dan terintegrasi (e-KTP). SIM adalah bagian dari identitas kewarganegaraan yang berlaku secara nasional. Oleh sebab itu, layanan SIM keliling secara offline pada dasarnya tidak memberikan kemudahan bagi warga negara. Misalnya di Kabupaten, jumlah masyarakat pendatang tergolong banyak, yang dipicu oleh keberadaan lembaga pendidikan, industri dan faktor-faktor lainnya. Beberapa pemicu tersebut tentunya menyulitkan masyarakat pendatang untuk mendapatkan layanan perpanjangan SIM. Hal ini karena mereka harus pulang ke wilayah masingmasing untuk mendapatkan layanan perpanjangan SIM. Oleh sebab itu, salah satu bentuk akuntabilitas institusi kepolisian terhadap layanan SIM keliling adalah menggeser semua layanan SIM keliling secara offline ke layanan secara online.

\section{SIMPULAN}

Akuntabilitas Ditlantas Polda Jawa Tengah dalam layanan SIM keliling tergolong rendah. Hal ini berdasarkan kinerja institusi kepolisan dinilai kurang optimal baik di tingkat provinsi maupun kabupaten/kota. Kinerja tersebut dilihat dari produk layanan SIM keliling yang tidak sesuai dengan jumlah pemilik mobil penumpang dan sepeda motor. Ada beberapa faktor yang mempengaruhi rendahnya kinerja institusi kepolisian dalam layanan SIM keliling di jawa tengah, yaitu (a) kuantitas dan kualitas sumber daya 
manusia/pegawai; (b) belum ada kolaborasi kepada pemangku kepentingan lain; dan (c) rendahnya sosialisasi kepada masyarakat.

Fasilitas layanan SIM keliling di Jawa Tengah juga menjadi penyebab rendahnya akuntabilitas Ditlantas Polda Jawa Tengah. fasilitas kunci, mobil layanan SIM keliling, tidak memadai dengan luas masing-masing wilayah di Jawa Tengah. Di sisi lain, masih ada wilayah yang melayanai SIM keliling secara offline. Layanan ini tidak terintegrasi, sehingga mengurangi kualitas layanan SIM keliling, khususnya bagi masyarakat pendatang.

Berdasarkan kesimpulan di atas, Ditlantas Polda Jawa Tengah harus mengevaluasi kinerja layanan SIM keliling di tingkat provinsi dan kabupaten/kota. Evaluasi di sini berupa menyusun kembali rencana/konsep, membentuk kolaborasi kepada pemangku kepentingan lainnya dan meningkatkan sosialisasi kepada masyarakat terkait layanan SIM keliling. Beberapa unsur tersebut dilakukan untuk menunjukkan konsistensi Ditlantas Polda Jawa tengah dalam pengambilan keputusan terkait layanan SIM keliling. Tindakan ini akan meningkatkan akuntabilitas institusi kepolisian, mengedukasi masyarakat dan meningkatkan kesadaran masyarakat tentang disiplin terhadap penggunaan jalan umum. Berikut adalah model rekomendasi untuk Ditlantas Polda Jawa Tengah.

Bagan 2. Model Rekomendasi.

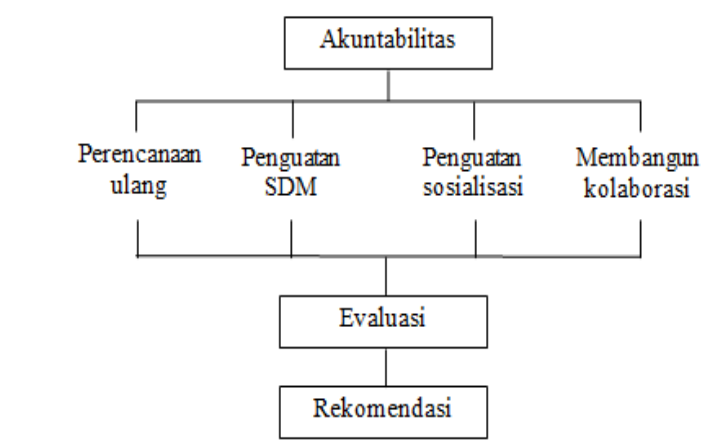

Sumber: Hasil Kerja Lapangan, 2021.

\section{DAFTAR PUSTAKA}

Andrews, R., Beynon, M., \& Genc, E. (2017). Strategy Implementation Style and Public Service Effectiveness, Efficiency, and Equity. Administrative Sciences, 7(1), 4. https://doi.org/10.3390/admsci7010004

Ashaye, O. R., \& Irani, Z. (2019). The role of stakeholders in the effective use of egovernment resources in public services.
International Journal of Information Management, 49, 253-270. https://doi.org/10.1016/j.ijinfomgt.2019.05. 016

Baú, V. (2018). Leaving the camps behind: the role of Development Communication in refugee-host integration. Communication Research and Practice, 4(4), 361-374. https://doi.org/10.1080/22041451.2018.14 31865

Chao, M., \& Shih, C. T. (2018). Customer servicefocused HRM systems and firm performance: evidence from the service industry in Taiwan. International Journal of Human Resource Management, 29(19), 2804-2826. https://doi.org/10.1080/09585192.2016.12 56904

Diansari, M. (2016). Analisis Kualitas Pelayanan Surat Ijin Mengemudi Kendaraan Motor ( SIM C ) di Polres Semarang 2016. Administrasi Publik, 6(2), 1-14.

Efriani. (2020). Analisis Kualitas Pelayanan terhadap Kepuasan Pelanggan pada Mobil Unit Pelayanan SIM Keliling di Kota Pekanbaru. 1(5), 440-450. https://doi.org/10.31933/JIMT

Fidianingsih, V., \& Fanida, E. H. (2020). Inovasi Layanan e-SIM (Elektronik Surat Izin Mengemudi) Sebagai Upaya Meningkatkan Pelayanan di Kepolisian Resort Kota Sidoarjo. Publika, 53(9), 1689-1699.

Guest, D. E. (2011). Human resource management and performance: Still searching for some answers. Human Resource Management Journal, 21(1), 3-13. https://doi.org/10.1111/j.17488583.2010.00164.X

Hadmiarso, T., \& Kismartini, K. (2020). Quality of Tour Driving License Services in Semarang Regency. Jurnal Administrasi Publik: Public Administration Journal, 10(2), 174-182. https://doi.org/10.31289/jap.v10i2.3603

Halim, A., dan S. Kusufi. 2013. Teori, Konsep, dan Aplikasi Akuntansi Sektor Publik. Jakarta: Salemba Empat

Handrian, E. (2019). Pelayanan Pembuatan Surat Izin Mengemudi Golongan C ( SIM C) Pada Sat Lantas Polresta Pekanbaru. Publika, 5(1), 137-155.

Hodgkinson, I. R., Hannibal, C., Keating, B. W., Chester Buxton, R., \& Bateman, N. (2017). Toward a public service management: past, present, and future directions. Journal of Service Management, 28(5), 998-1023. https://doi.org/10.1108/JOSM-01-20170020

Ikhwan, M., Sahari, A., \& Fauzi, A. (2020). Peran Direktorat Lalu Lintas Polda Sumatera Utara Dalam Menciptakan Akuntabilitas Pelayanan 
Publik. Journal of Education, Humaniora and Social Sciences (JEHSS), 3(1), 103-110. doi:https://doi.org/10.34007/jehss.v3i1.204

Kekez, A., Howlett, M., \& Ramesh, M. (2018). Varieties of collaboration in public service delivery. Policy Design and Practice, 1(4), 243-252.

https://doi.org/10.1080/25741292.2018.15 32026

Lee, S. Y., \& Kim, J. H. (2014). Effects of servicescape on perceived service quality, satisfaction and behavioural outcomes in public service facilities. Journal of Asian Architecture and Building Engineering, 13(1), 125-131. https://doi.org/10.3130/jaabe.13.125

Matsiliza, N., \& Zonke, N. (2017). Accountability and Integrity as Unique Column of Good Governance. Public and Municipal Finance, 6(1), 75-82. https://doi.org/10.21511/pmf.06(1).2017.0 8

Miles, M. B., Huberman, A. M., \& Saldaña, J. (2014). Qualitative Data Analysis, A Methods Sourcebook, Edition 3. USA: Sage Publications. In Qualitative Data Analysis, A Methods Sourcebook, Edition 3. USA: Sage Publications. https://doi.org/10.7748/ns.30.25.33.s40

Moynihan, D., Herd, P., \& Harvey, H. (2015). Administrative burden: Learning, psychological, and compliance costs in citizen-state interactions. Journal of Public Administration Research and Theory, 25(1), 43-69.

https://doi.org/10.1093/jopart/muu009

Mardiasmo. (2006). Pewujudan Transparasi dan Akuntabilitas Publik Melalui Akuntansi Sektor Publik: Suatu Sarana Good Governance. Jurnal Akuntansi Pemerintah 2 (1): 1-17.

Nasution, F.R. dan Rudi S.S., (2014). Evaluasi Kinerja Pegawai Kantor Samsat dalam Pelayanan Bea Balik Nama Kendaraan Bermotor, JPPUMA: Jurnal Ilmu Pemerintahan dan Sosial Politik UMA (Journal of Governance and Political UMA), 2 (1): 1-17.

Osborne, S. P., Radnor, Z., \& Nasi, G. (2013). A New Theory for Public Service Management? Toward a (Public) Service-Dominant
Approach. American Review of Public Administration, 43(2), 135-158. https://doi.org/10.1177/027507401246693 5

Lindawati, L., \& Lubis, A. (2016). Peranan Kantor Perpustakaan, Arsip dan Dokumentasi dalam Peningkatan Pelayanan bagi Masyarakat, JPPUMA: Jurnal Ilmu Pemerintahan dan Sosial Politik UMA (Journal of Governance and Political UMA), 4 (1): 43-58.

Purnamasari, H., Ramadhan, M. B., Bashar, H. S., \& Noviyanti, D. (2020). Kualitas Pelayanan Publik dalam Pembuatan Surat Izin Mengemudi Kendaraan Motor (SIM C) di Polres Karawang. Jurnal Politikom Indonesiana; Kajian Ilmu Pemeirntahan, Ilmu Politik Dan Ilmu Komunikasi, 5(2), 64-74.

Sarmini, A. (2019). Kualitas Pelayanan Surat Izin Mengemudi (SIM) Pada Kantor Satuan Lalu Lintas Polres Karimun. Soumatera Law Review, 2(2), 246-257.

Sun, X. (2017). Research and Prospect of Collaborative Governance Theory. Public Policy and Administration Research, 7(7), 4. file:///C:/Users/03970/Downloads/3811541199-1-PB (2).pdf Badan Pusat Statistik Jawa Tengah, 2020. Keputusan Menteri Pendayagunaan Negara No. 63 Tahun 2003 tentang Petunjuk Teknis Transparansi dan Akuntabilitas ddalam Penyelenggaraan Pelayanan Publik.Subditregident Ditlantas Polda Jawa Tengah, 2019. Subditregident Ditlantas Polda Jawa Tengah, 2020

Samsudin, M. (2021). Analisis Kinerja Pelayanan Publik tentang Sumber Daya Manusia dan Responsivitas Pegawai di Kantor Kelurahan Kecandran Kecamatan Sidomukti Kota Salatiga. Journal of Education, Humaniora and Social Sciences (JEHSS), 4(2), 1028-1034. doi:https://doi.org/10.34007/jehss.v4i2.794

Tampubolon, M., Jannah, M., Gultom, R., \& Sibarani, H. (2020). Pengaruh Sistem Pelayanan, Ketepatan Waktu dan Daya Beli Masyarakat terhadap Loyalitas Menggunakan Jasa Transportasi Bus pada PT. Atlas. Journal of Education, Humaniora and Social Sciences (JEHSS), 3(2), 566-576. doi:https://doi.org/10.34007/jehss.v3i2.363 